\title{
Impact of Social Media Usage on Organizational Performance in the Jordanian Dead Sea Cosmetic Sector
}

\author{
Ardam Dodokh $^{1 *} \quad$ Mohammad Atwah Al-Maaitah ${ }^{2}$ \\ 1.Middle East University, Department of Business, Amman, Jordan \\ 2.Al-Balqa' Applied University, Department of Business, Amman, Jordan
}

\begin{abstract}
Due to the current debate on the positives and negatives of social media, most of the organizations are in an unclear state regarding the adoption of social media. Therefore, the purpose of this paper is to extend previous research on social media use comprising three variables: social media for marketing, social media for customer's relations and services, and social media for information accessibility and its impact on organizational performance in terms of rapid adaptation, time to market, cost reduction, and innovation in Jordan. The paper analyzed data obtained from a sample of 169 managers working at 23 different organizations in Dead Sea cosmetic sector in Jordan using a quantitative approach. Structural equation modelling used to test the hypotheses. Results showed that there is a strong positive impact of implementing and using social media on organizational performance in terms of rapid adaptation, cost reduction, and innovation. Also, social media usage is different among the companies' characteristics in terms of type, age, and size. This paper offers a clearer understanding of the importance of social media and its benefits. Also, this paper is one of the first studies conducted in Jordan and especially within the Dead Sea cosmetic sector by demonstrating the different areas of organizational performance that can be enhanced by using social media in different ways.
\end{abstract}

Keywords: Social media, social media marketing, customer relations, organizational performance, rapid adaptation, cost reduction, time to market, innovation, Dead Sea cosmetic, Jordan.

DOI: $10.7176 / \mathrm{EJBM} / 11-2-09$

\section{Introduction}

Organizations are now building and maintaining social media public pages to improve their social network salience, enhance interest in their organizations, and build relationships with the online public (Parveen et al., 2015). In this context, social media has turned into the primary drive behind Jordanians connecting to the Internet. The average age of Facebook users in Jordan with over one million users is from 18-24, followed by 25-34 years old, which clears the importance of adopting and utilising the right marketing strategy on social media for organizations in Jordan to cover this vast audience (Yaseen, 2016).

Jordan has been investing significantly in developing ICT sector, to improve the performance of public and private sector using service providing, effectiveness, accurateness, time and satisfaction, and the diffusion of ICT in the organization strategy is vital to reach productivity, growth, and efficiency (JTRC, 2017). However, social media marketing strategies are still new in Jordanian organizations especially small and medium enterprises, and it is valuable to explore its benefits, risks, challenges, and opportunities also to discover its positive or negative impacts by using and adopting social media in Jordanian organizations (Al Tawara and Gide, 2017). In addition, most of the Jordanian small and medium organizations are using traditional media for their marketing strategies, but they cannot rely on it, they have to adopt and explore on how to utilize their interactive social media as part of their marketing strategies to become more connected with their customers and, by doing so, increase revenue, reduce costs and improve effectiveness (Akar and Topeu, 2011).

Accordingly, it seems like that the most effective social media platform for Jordanian organizations is on Facebook, which has a varied range of audience with over one billion of users on Facebook. Also, smartphone users in Jordan are growing every day by using social media platforms for online shopping, socialising, share knowledge and information about products or brands (Al Tawara and Gide, 2017). Accordingly, Jarad (2014) argued that social media is a vital marketing tool that will raise marketing efficiency in any organization, for that reason it is an essential need to study how various industries and sectors use social media and the purpose of adopting it. Therefore, Jordanian government must adopt strategies to attain a new, high-quality Internet infrastructure and increase national awareness of the Internet and social media to the organizations by increasing investment in the ICT infrastructure (Al-Weshah et al., 2011).

Academic research on social media is still not complete in the context of insightful investigations into the different purposes of social media usage and subsequent impacts on organizations (Schultz et al., 2012), and in order to understand the potential of social media, it is critical to investigate the various purposes of social media usage and its impact on organizational performance. However, only a limited number of studies have investigated the actual impact of social media usage on organizational performance (Parveen et al., 2016; Parveen et al., 2015). Therefore, a number of scholars calls for the need of more research on social media in organizational context in different countries and environment (Al Tawara and Gide, 2017; Berthon et al., 2012; 
Okazaki and Taylor, 2013; Parveen et al., 2016; Parveen et al., 2015), for the reason that there might be a difference in laws, culture, technology and environment that could impact the use and acceptance of new communication technologies; and that this may be so in Jordan. More precisely, implementing social media in Jordanian organizations is still new (Al Tawara and Gide, 2017) and only limited research conducted in Jordan on work-related and non-work related social media use in organizations. Moreover, Alkhoms and Alnsour (2013) called for future research on social media use in different sectors in Jordan and explicitly taking into considering demographics in future researches which can reveal their influences more clearly.

More specifically, only a limited number of research conducted in the Jordanian Dead Sea cosmetic sector (Tamimi, 2017). The Dead Sea products have high international demands. However, social media are rarely used professionally by the Dead Sea products companies in Jordan (Tamimi, 2017; Tamimi, 2012). Also, there are weaknesses in the marketing strategies of the companies' manufacturing and exporting Dead Sea products in Jordan (Tamimi, 2017). Accordingly, this sector should take advantage of this international demand by using social media within their marketing strategy. Therefore, this study is conducted to fill this gap by delivering a deep understanding of social media usage in the Jordanian Dead Sea sector. By extending the previous research conducted in social media use, this study aims to investigate the impact of social media usage comprising three variables, namely social media for marketing, social media for customer's relations and services, and social media for information accessibility, on rapid adaptation, time to market, cost reduction, and innovation.

This research is vital for the reason it delivers an understanding of the degree of social media usage in Jordan especially on how can organizations implement and develop social media into their marketing strategies. Also, the importance of the study represents from the theoretical side in being one of the first studies to the knowledge of the researchers which addressed the impact of the social media uses on organizational performance in Jordan especially in the Dead Sea cosmetic sector, which considers new scientific addition to the information system literature. Accordingly, the main question of this study is "How can social media usage impact organizational performance in terms of rapid adaptation, time to market, cost reduction, and innovation?".

The next section of the paper reviews the literature on the organizational use of social media and related previous studies, followed by the research hypotheses. Then, the research methodology and analysis followed by the research findings then describes the practical implications of the research and also provides guidelines for future research then the study conclusion.

\section{Literature Review}

Social media consisted of a collection of internet-based tools work on web technology and ideological basis which help users to create content and share it with other users (Kaplan and Haenlein, 2010). Social media have several forms and types like; blogs, microblogs, social networks, media-sharing sites, social bookmarking and voting sites, evaluation sites, forums, and virtual worlds (Zarella, 2010). Social media are characterized by usergenerated content, which has been found to be more effective than traditional marketing communications in influencing the attitudes and behaviours of other users (Thackeray et al., 2008). The use of social media in businesses was considered a failure, but this changed quickly as the rapid increase trend of social media. For instance, over 4 billion internet users exist today of which more than 3 billion users are active in social media (Chaffey, 2018). Therefore, organizations must know how to make use of social media sites to force traffic to their business sites (Weinberg, 2009).

Social media first started with LinkedIn in (2003), taken after by MySpace and Facebook in (2004), YouTube in (2005), and Twitter in (2006). In less than ten years, it has achieved billions of users around the world (Barker et al., 2016). People used tools like Facebook and blogs long before organizations became aware of social media and grasped the potential they held (Gonzalez et al., 2015). Accordingly, using online networking widely spread to organizations and firms as a feature of their systems. For example, Facebook's vice president of small business stated that paid advertisement of Facebook has become effective and companies should put their efforts to their Facebook page for growing their business and boost the marketing (Loten et al., 2014). Also, $86 \%$ of 100 biggest organizations on the Fortune 500 rundown use at least one of the online networking platforms, and $28 \%$ of them utilize every online networking platform available (Tsitsi et al., 2013). Accordingly, companies are using social media to promote their products in a new way, and each social media has its distinct purpose that the other media may not have.

\subsection{Social Media for Customer Relations and Services}

Social media has significantly changed the relationships among customers and organization by creating and allowing a two-way communication (Hoyer and MacInnis, 2010). Also, social media websites provide organizations with the potential to interrelate with a prospect and present customers, to boost the sense of the closeness of the customer relationship (Mersey et al., 2010). Accordingly, social media has not only transformed the manner in which organizations and their brands interact with customers but in several ways, it has similarly changed the way business is conducted (Leeflang et al., 2014; Patino et al., 2012; Schulz and Peltier, 2013). For 
instance, actively promoting the organization with trending ways such as hashtags in Facebook and Twitter helps to raise brand awareness and reliability (Caruso, 2016).

"The power of the Internet makes it easier for people to fall in love with you faster. However, beware, it also makes it easier for them to fall out of love with you faster, it is a double-edged sword" (Scott, 2009, p.11). Therefore, customers believe that social media sites are a service channel, where they can be capable of interrelating on real-time bases with the businesses, were customer often seek from checking social media sites to keep up with a brand's products and promotional campaigns (Mangold and Foulds, 2009). Accordingly, consumers, these days are extra inelegant, knowledgeable and more difficult; for that reason, organizations must be reachable and available at any time in each social media communication channel such as Facebook, Twitter, and Blogs (Gordhamer, 2009). Some companies confirmed that they could easily change the negative vibes from customers by responding to them quickly (Bughin, 2015). Therefore, providing rich information with better customer support as quickly as possible helps to increase the annual sales and financial gain, helps connect businesses to customers, build up relationships and cultivate those relationships (Coen, 2016; Copp, 2016; Kaplan and Haenlein, 2010).

\subsection{Social Media for Marketing}

Using social media can be a useful tool in the marketing field; it can reach the targeted audience with the least cost possible, reaching interested individuals regardless of their geographical areas, and at the same time help in building potential customers (Pradiptarini, 2011). Research explains many methods on how customers can interact with firms and their brands such as consumer engagement with brand Facebook pages, creating brand content on YouTube or Twitter using some social media platforms (Gironda and Korgaonkar, 2014; Kim et al., 2014; Muk and Chung, 2014; Smith et al., 2012). In a report about the use of social media in marketing by Stelzner (2016) found out that nearly $60 \%$ of marketers use the video tools that are supported through social media for marketing purposes, and more marketers are now using the new hot tool of the live video streaming. Also, activities like engaging customers by sharing relevant contents in social media, collecting feedbacks and responding them wisely, and eventually adjusting marketing strategy from feedback increases the web traffic which leads to appear on top in search engine optimization (Dane, 2016). In addition, using social media to track the activities of competitors and analyzing the result to use in business helps to upgrade business followed by upgrading plans, such as offering discounts and other offers to attract more customers (Caruso, 2016).

\subsection{Social Media for Information Accessibility}

Social media can improve information accessibility by helping organizations to attain more information about the market, new trends, industrial information, feedback on products, competitors and their tactics, customers and their needs (Parveen et al., 2013). Therefore, organizations can efficiently deliver their organizational information to the public promptly by using social media (Parveen et al., 2016). Accordingly, social media can generate a word-of-mouth recommendation (Chang et al., 2016) and the impact of word-of-mouth in marketing is non-negligible, especially in online environments (Gruen et al., 2006; Leung and Baloglu, 2015). Therefore, potential customers go through social networking sites to find what other customers have reviewed a specific product before buying (Erkan, 2014). Furthermore, information in the electronic word of mouth can be accessed and supplemented by using elements such as emoticons, videos, and pictures (Velazquez et al., 2015).

\subsection{Social Media and Organizational Performance}

The corporate adoption of social media provides many benefits, and several have identified a positive relationship between social media adoption and corporate performance (Ainin et al., 2015; Paniagua and Sapena, 2014; Parveen et al., 2013; Rodriguez et al., 2015). For example, Rodriguez et al. (2015) found that social media use had a positive effect on customer-facing activities and therefore sales performance. Similarly, Kwok and Yu (2013) found that Facebook adoption had a positive effect on SMEs' sales performance. In addition, the adoption of social media has been found to positively affect organizational social capital, which in turn affects performance (Ferrer et al., 2013). Likewise, Hassan et al. (2015) noted that social media could have a significant impact on business by significantly influence purchasing decisions. These studies are consistent with previous technology adoption literature that found that technology adoption had a positive impact on the financial and non-financial performance (Parveen et al., 2013; Scupola and Nicolajsen, 2013; Thong, 2001).

Organizations must act in response to changes and be obliged to have individuals able to deal with the associated facing challenges regularly, and Feedbacks received from social media sites could be utilized to upgrade business plans and make changes admitting the desire of loyal customers (Dane, 2016; Olof Lagrosen and Grundén, 2014). In addition, using social media to track the activities of competitors and analyzing the result to use in business helps to upgrade business followed by upgrading plans, such as offering discounts and other offers to attract more customers (Caruso, 2016). Accordingly, by implementing social media within the marketing strategy, organizations can acquire additional information about the market, competitors, and 
primarily their customers and their requirements which will improve the information accessibility of the organizations and their ability to adapt to sudden changes (Parveen et al., 2013). Therefore, the following hypotheses were formulated:

H1a: Social media for customer relations and services has a direct positive impact on rapid adaptation.

H1b: Social media for marketing has a direct positive impact on rapid adaptation.

H1c: Social media for information accessibility has a direct positive impact on rapid adaptation.

Time to market defined as the span of time it takes to design a new and fresh product from an early initial idea for a new product to initial market sales, therefore, the market timing decision during an arduous product development process depends on whether the firm should invest more time in manufacturing process design and improvement or push the product to market before competitors (Özer and Uncu, 2015). Accordingly, organizations are continually working to lessen their time to market new products as a base of competitive advantage. Therefore, using social media in business would be a best-fit concept as it helps to niche the target customers effectively and businesses would be able to share the content of their products and services almost instantly (Derham et al., 2011). Similarly, social media can be used for connecting with customers, thereby contributing to customer learning and getting customer input (Tikkanen et al., 2009). Also, Jackson (2011) stated that at least half of Twitter and Facebook users stated that they had become more likely to chat about, recommend or buying a company's products after they began following the company on social media. Accordingly, Kimani (2015) stated that social media marketing has much value to people because it allows employees to connect with the clients, especially the ones in different geographic zones, and it helps organizations to engage in timely and direct end-consumer contact at reasonably low cost and higher ranks of efficiency more than can be attained with more traditional communication tools.

Social media enable organizations to improve the client collaboration that has just been set up through conventional media to a more individual level, which has empowered organizations to create nearer associations with their clients, and also to extend the market to the clients that they couldn't reach some time recently (Keegan and Rowley, 2017). Therefore, the engagement through social media has a positive effect on electronic word of mouth intention, which can help to upgrade business followed by upgrading plans, such as offering discounts and other offers to attract more customers or developing a new product based on feedback from social media (Caruso, 2016; Okazaki and Yagüe, 2012). Hence, it is hypothesized that:

H2a: Social media for customer relations and services has a direct positive impact on time to market.

H2b: Social media for marketing has a direct positive impact on time to market.

H2c: Social media for information accessibility has a direct positive impact on time to market.

Using social media allows organizations to perform integrated marketing activities with much less effort and cost than before (Kim and Ko, 2012), and organizations that use and implement the newest social media technologies seem to outperform their competitors with additional benefits like lower costs and better efficiencies (Eisenfeld and Fluss, 2009; Harris and Rea, 2009). Accordingly, Parveen et al. (2016) stated that social media usage has a positive impact on organizations' performance, regarding cost reduction, improved customer relations, and enhanced information accessibility. Furthermore, social media can have a significant impact on organizations in digital advertising and promotion, handling customer service issues, mining innovative ideas, and building customer relations (Paridon and Carraher, 2009; Solis, 2010).

Cost-effectiveness of social media can be considered as one of the key factors that are linked to social media usage in organizations (Kaplan and Haenlein, 2010). Social media can even be used by small and medium-sized enterprises (SMEs) due to its low cost and minimal technical requirements (Derham et al., 2011). Therefore, social media use continues to grow largely among businesses (Mourtada and Alkhatib, 2014) and is quickly turning to a crucial business management phenomenon (Trainor et al., 2014). More specifically, comparing with traditional communication tools, firms can engage through social media in a timely and direct end-consumer contact at relatively low cost, and higher levels of efficiency (Parveen et al., 2016), this costeffective nature of social media attracts large multinational organizations, SMEs, non-profit organizations, and governmental agencies (Kaplan and Haenlein, 2010). Therefore, it is hypothesized that:

H3a: Social media for customer relations and services has a direct positive impact on cost reduction.

H3b: Social media for marketing has a direct positive impact on cost reduction.

H3c: Social media for information accessibility has a direct positive impact on cost reduction.

In highly competitive industries, where technological knowledge is crucial including the capability to explore technological opportunities, core technology capability, and autonomous R\&D decisions are particularly important to create innovation capability (Huang, 2011). When using technology like social media, it enables organizations to engage in open communication with customers, which can have an impact on the organizations' perceived image or brand and their image of being innovative and market leaders (Zyl, 2009). One of the essential uses of social media is that innovation can be encouraged by observing customer communications, feedback, and opinions (Matuszak, 2007; Tapscott and Williams, 2006). Therefore, entrepreneurs in the small industries need to understand the techniques to influence their brands and services through electronic word of 
mouth communication process in social media, and features like participation, social connection, innovativeness and experiences are the key factors contributing to spread electronic word of mouth in social networks (Leung and Baloglu, 2015), which can help the organization in competitive business environment (Kucukemiroglu and Kara, 2015).

Social media can play a crucial role in the future of marketing; externally it can replace customer annoyance with engagement, and internally it can help to change the traditional focus on control with an open and collaborative approach that is more conducive to success in the modern business environment (Harris and Rae, 2009). Organizations using social media are eager to take risks and invest in new products and services to satisfy customers, to get improved feedback, and develop the brand image. Additionally, social media improve digital marketing and promotion, the management of customer service issues, mining innovative ideas, and building customer relations (Solis, 2010). Similarly, organizations that are using social media are more likely to change from the traditional way of doing business to a more modern and innovative way (Parveen et al., 2016). Therefore, it is hypothesized that:

H4a: Social media for customer relations and services has a direct positive impact on innovation.

H4b: Social media for marketing has a direct positive impact on innovation.

H4c: Social media for information accessibility has a direct positive impact on innovation.

\subsection{Control Variables}

In this study, the size, age, and type of the organization were used as control variables. Organization size has been found to have a positive influence on adoption behavior (Rogers, 1995). Previous studies had reported that larger organizations are more likely to adopt new technologies (LaRose and Hoag, 1996; Min and Galle, 2003; Papastathopoulou and Avlonitis, 2009). Regardless of its size, social media can be used by any organization. However, larger organizations have sufficient resources and staff to monitor the usage effectively, so the impact of social media usage on performance may be more visible for them. Therefore, it is important to use organization size as one of the control variables. Accordingly, this study categorised organizations by the number of employees into three groups namely, small (less than 5), medium (5-20), and large (20+). It was found that there are differences of the adoption and the success of the marketing strategies due to the company type among the Jordanian Dead Sea cosmetic sector (Tamimi, 2017). Therefore, this study used the type of the company as another control variable, which was categorized by the Jordanian companies control department under three main categories as limited liability, public shareholding, and private shareholding. In addition, technology usage can differ between young and old organizations, and when usage differs, its impact on the organizations' performance can also differ (Parveen et al., 2016). Therefore, the age of the organization was also applied as a control variable in this study by categorizing organizations into three groups, namely, less than 5 years, 5-10 years, and more than 10 years.

\subsection{Research Model}

Figure 1 outlines the conceptual model and hypotheses. The model is empirically tested based on twelve hypotheses. This study proposes that social media use has a positive impact on organizational performance regarding rapid adaptation, time to market, cost reduction, and innovation.

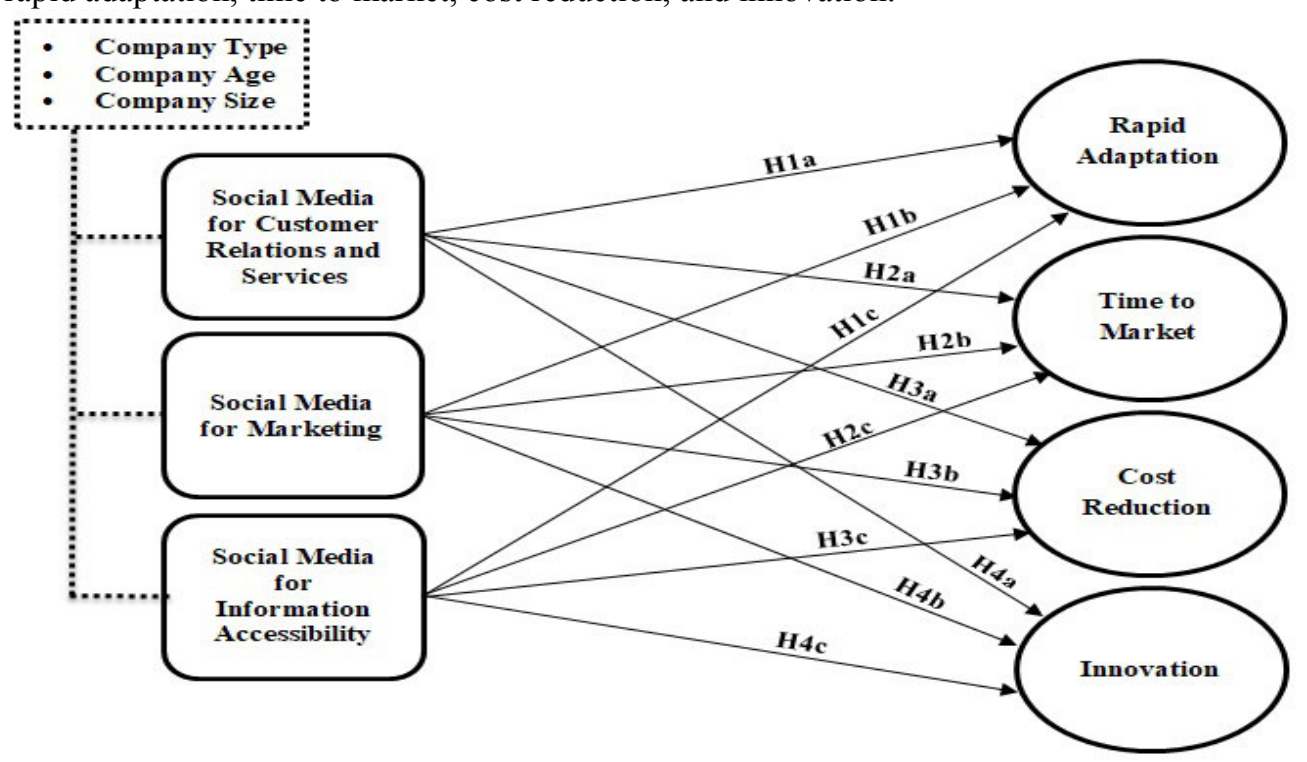

Figure 1. Conceptual Model and Hypotheses 


\section{Research Methodology}

\subsection{Participants}

The target population for the study included organizations in Jordanian Dead Sea sector. In order to identify the sample for this study, a list of Jordanian Dead Sea products organizations was created from a reliable government source the Jordanian Companies Control Department. Overall, a list of 25 organizations from different demographic locations across Jordan was retrieved from the source. Each of the organization's websites was browsed to identify the organizations that are using social media, among the 25 organizations; only 23 organizations have an official social media presence which was included for the data collection. Additionally, it is also essential to define the respondents that represent the unit of analysis (Hair Jr et al., 2017). Therefore, following the most commonly used method in organizational research, the single key-informant approach (Kumar et al., 1993), key organizational informants such as the managers and senior staff from corporate communication or marketing department or the head of the social media team are the respondents (Parveen et al., 2016).

After identifying the organizations in the Jordanian Dead Sea sector that use social media, this study used the quantitative survey method for collecting data from the respondents using a structured survey method. The managers and senior staff of all the 23 organizations from the marketing department were contacted. In addition, it was confirmed that the participation in the survey is voluntary with no foreseeable risks involved in participating. After obtaining their consent and ensuring confidentiality, the questionnaire was distributed by hand to 200 managers in Dead Sea cosmetic sector in Jordan. After reminders were provided, 169 usable responses were received showing a response rate of $84 \%$.

\subsection{Measures}

This study categorizes social media usage into three sub-constructs, social media used for information searching, social media used for marketing and branding, and social media used for customer relations and services (Parveen et al., 2016). All of the items for the three types of usage were adapted from previous studies in order to cover various dimensions of the usage construct (Boshoff and Elliot, 2005; Moen et al., 2008; Papastathopoulou and Avlonitis, 2009; Teo and Choo, 2001), by using a five-point Likert scale ranging from 1= strongly disagree to $5=$ strongly agree was used. This study also categorized organizational performance into constructs namely, rapid adaptation, time to market, cost reduction, and innovation. All of the items were adapted from previous studies (Boxal, 2003; DeLone and McLean, 1992; Feher and Towell, 1997; Teo and Choo, 2001), by using a five-point Likert scale ranging from $1=$ strongly disagree to $5=$ strongly agree was used. The items and their sources are presented in Appendix A.

Most companies in the Dead Sea cosmetic sector in Jordan are limited liability companies (60\%), while the least is public shareholding (17\%) and most of them considered as medium companies (from 5 to 20 employees) (52\%). Accordingly, Table 1 below shows the characteristics of the companies and respondents' demographic characteristics.

Table 1. Companies characteristics

\begin{tabular}{clcc}
\hline Dimension & & Frequency & $\%$ \\
\cline { 2 - 5 } Company & Limited liability & 14 & 60 \\
Type & Public shareholding & 4 & 17 \\
& Private shareholding & 5 & 21 \\
\hline \multirow{2}{*}{ Company } & Less than 5 employees & 3 & 13 \\
Size & $5-20$ employees & 12 & 52 \\
& More than 20 employees & 8 & 34 \\
\hline \multirow{2}{*}{ Company } & Less than 5 years & 5 & 21 \\
Age & $5-10$ years & 10 & 43 \\
& More than 10 years & 8 & 34 \\
\hline
\end{tabular}

\section{Data Analysis}

Data analysis was performed using a component-based approach, Partial Least Square using SmartPLS 3.2.8. PLS is a statistical technique that provides higher flexibility than covariance-based structural equation modelling (SEM) since it is not required for the data to be normally distributed, also PLS allows smaller sample sizes in the analysis (Hair Jr et al., 2017). As well, it has a high tolerance for deviation from normality and is convenient for theory development (Bassellier and Benbasat, 2004). Before PLS model estimation, it is important to perform a series of analysis to ensure the validation and validity of measurements and to calculate the common method bias. 


\subsection{Measurement Validation}

Validity refers to whether the research findings are really about what they appear to be about (Saunders et al., 2016). One of the most useful tests for internal reliability is Cronbach's alpha, which measures to what extent the items of a construct are correlated and therefore measure the same aspect (Bryman, 2012). The threshold for Cronbach's alpha test is 0.70; therefore, the higher the value, the more reliable the measure is (Hair Jr et al., 2017; Nunnally and Bernstein, 1994). Accordingly, it was found that all the constructs are above the recommended threshold of 0.70 . Therefore, all items of the constructs are retained. The results are given in Table 2 .

Table 2. Reliability test

\begin{tabular}{|c|c|c|c|c|}
\hline Variable & Mean & SD & Cronbach's Alpha & Composite Reliability \\
\hline Social media for marketing & 3.550 & 0.987 & 0.797 & 0.788 \\
\hline Social media for customer relations and services & 2.920 & 1.330 & 0.937 & 0.937 \\
\hline Social media for information accessibility & 3.400 & 1.115 & 0.862 & 0.861 \\
\hline Rapid adaptation & 3.422 & 1.052 & 0.909 & 0.909 \\
\hline Time to market & 3.050 & 1.252 & 0.898 & 0.898 \\
\hline Cost reduction & 3.530 & 1.088 & 0.870 & 0.870 \\
\hline Innovation & 3.320 & 1.191 & 0.910 & 0.909 \\
\hline
\end{tabular}

$N=169$.

\subsection{Discriminant Validity}

Exploratory factor analysis (EFA) was conducted to assess the construct validity of the scales further. The result of a principal component analysis with Varimax rotation generated eleven factors for the eleven constructs. All the items loaded strongly on their respective factors, indicating a general unidimensional structure of the instrument (Hair Jr et al., 2017). In the second stage of measurement validation, a confirmatory factor analysis (CFA) was conducted to assess the discriminant validity of all construct measures further. Hair Jr et al. (2017) suggested a minimum of 0.5 for good convergent validity. The analysis indicated that the factor loadings of all constructs meet this minimum requirement and satisfactory discriminant validity of all constructs as shown in Table 3.

Table 3. Construct correlations

\begin{tabular}{|c|c|c|c|c|c|c|c|}
\hline Item & 1 & 2 & 3 & 4 & 5 & 6 & 7 \\
\hline Cost reduction & .831 & & & & & & \\
\hline Innovation & .700 & .817 & & & & & \\
\hline Rapid adaptation & .787 & .779 & .817 & & & & \\
\hline Social media for customer relations & .679 & $.704 * *$ & $.764 * *$ & .865 & & & \\
\hline Social media for information accessibility & $.767 *$ & $.690 * * *$ & $.771 * * *$ & .789 & .745 & & \\
\hline Social media for marketing & $.754 * *$ & .626 & $.559 *$ & .634 & .755 & .658 & \\
\hline Time to market & .545 & .458 & .408 & .398 & .440 & .355 & .829 \\
\hline
\end{tabular}

$N=169 . * * * P<0.001, * * P<0.01, * P<0.05$.

\subsection{Common Method Bias}

A number of proactive steps were taken to minimize the risk of common method bias during the survey instrument design and execution. First, the survey items were worded in a way to reduce social desirability, including through the avoidance of phrases such as "wasting time". Second, the items were tested for clarity in the pre-testing phase. Third, by stating in the opening statement of the questionnaire that it is anonymous, confidential, there is no right or wrong answer, and the first answer is likely to be the best. This assurance can encourage participants to reduce the tendency to worry about being consistent, rational, socially acceptable, and positive (Thornton and Gupta, 2004).

In addition, Harman's single-factor test was conducted and generated eleven un-rotated factors. Results should be less than 50\% (Podsakoff et al., 2003). The largest amount of covariance explained by a single factor was $47 \%$, this result suggested that common method bias was unlikely to contaminate the results. Based on the above tests, it was concluded that the scales were reliable and valid and were suitable for hypotheses testing.

\section{Results}

The structural model of the PLS regression analysis including the standardized coefficient and $t$ values were calculated using a bootstrap resampling technique was used to test the hypotheses (Efron, 1979). This study used a resampling procedure with 1000 subsamples to assess the significance of the hypothesized relationships and the amount of variance in the dependent variables attributed to explanatory variables (Chin, 1998). Figure 2 presents the results of the proposed model estimates which includes the standardized path coefficients associated 
with each proposed hypothesis, the significance of the path coefficients, and the variance explained $\left(\mathrm{R}^{2}\right)$ by the independent variables.

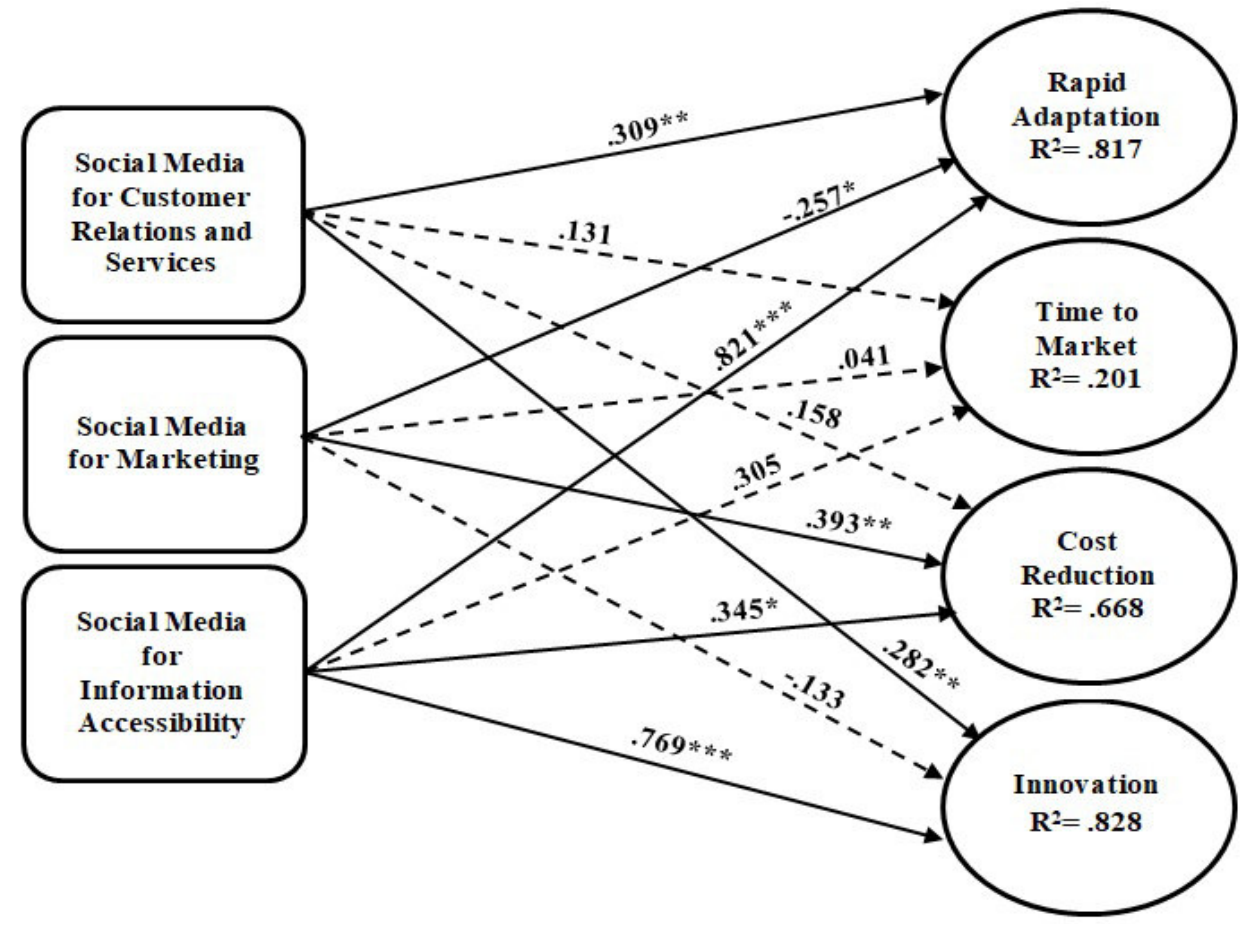

$N=169, * * * P<0.001, * * P<0.01, * P<0.05$

Solid lines represent significant paths.

All control variables are pointed to all of the independent variables.

Figure 2. PLS Test Results

Social media usage explained $81 \%$ of the variance in the rapid adaptation variable, $20 \%$ of time to market, $66 \%$ of cost reduction, and $82 \%$ of innovation variable. Summary of the hypotheses testing results is presented in Table 4.

Table 4. Path coefficients and hypotheses testing

\begin{tabular}{lllccc}
\hline & Path from & Path to & Coefficient & P Values & Supported? \\
\hline H1a & SM for customer relations and services & Rapid adaptation & .309 & 0.008 & Yes \\
H1b & SM for marketing & Rapid adaptation & -.257 & 0.021 & No \\
H1c & SM for information accessibility & Rapid adaptation & .821 & 0.000 & Yes \\
H2a & SM for customer relations and services & Time to market & .131 & 0.352 & No \\
H2b & SM for marketing & Time to market & .041 & 0.810 & No \\
H2c & SM for information accessibility & Time to market & .305 & 0.153 & No \\
H3a & SM for customer relations and services & Cost reduction & .158 & 0.131 & No \\
H3b & SM for marketing & Cost reduction & .393 & 0.006 & Yes \\
H3c & SM for information accessibility & Cost reduction & .345 & 0.039 & Yes \\
H4a & SM for customer relations and services & Innovation & .282 & 0.008 & Yes \\
H4b & SM for marketing & Innovation & -.133 & 0.219 & No \\
H4c & SM for information accessibility & Innovation & .769 & 0.000 & Yes \\
\hline$N=169$ & & & &
\end{tabular}

Several control variables were collected in this study to rule out rival hypotheses and potentially aid in the interpretation of the results. In particular, the results shows that the company type have a significant relationship with using social media for customer relations and services $(\beta=-.151, p<.01)$, for marketing $(\beta=-.293, p$ $<.001)$, and for information accessibility $(\beta=-.198, \mathrm{p}<.001)$. Also, results shows that the company size have a significant positive relationship with using social media for customer relations and services $(\beta=.340, p<.001)$, for marketing $(\beta=.259, \mathrm{p}<.001)$, and for information accessibility $(\beta=.307, \mathrm{p}<.001)$. Also, results shows that the company age have a significant positive relationship with using social media marketing $(\beta=.296, p<.001)$, and for information accessibility $(\beta=.229, \mathrm{p}<.05)$. Accordingly, this study reveals that there is a difference in respondents members based on the company's characteristics on social media usage. Furthermore, Scheffe testing conducted in Table 5 to determine which has the strongest difference within each variable in the company type, company size, and company age. 
Table 5. Control variables Scheffe testing

\begin{tabular}{|c|c|c|c|c|c|c|c|}
\hline \multirow{2}{*}{ Item } & \multirow{2}{*}{ (I) } & \multirow{2}{*}{$(\mathrm{J})$} & \multirow{2}{*}{$\begin{array}{c}\text { Mean } \\
\text { difference (I-J) }\end{array}$} & \multirow{2}{*}{$\begin{array}{l}\text { Std. } \\
\text { error }\end{array}$} & \multirow{2}{*}{ Sig. } & \multicolumn{2}{|c|}{$\begin{array}{l}95 \% \text { confidence } \\
\text { Interval }\end{array}$} \\
\hline & & & & & & $\begin{array}{l}\text { Lower } \\
\text { bound }\end{array}$ & $\begin{array}{l}\text { Upper } \\
\text { bound }\end{array}$ \\
\hline \multirow{6}{*}{$\begin{array}{l}\text { Company } \\
\text { type }\end{array}$} & \multirow{2}{*}{ Limited } & Public & $27.443^{*}$ & 4.979 & 0.000 & 15.144 & 39.743 \\
\hline & & Private & $21.143 *$ & 5.550 & 0.001 & 7.434 & 34.853 \\
\hline & \multirow{2}{*}{ Public } & Limited & $-27.443 *$ & 4.979 & 0.000 & -39.743 & -15.144 \\
\hline & & Private & -6.300 & 7.355 & 0.693 & -24.467 & 11.867 \\
\hline & \multirow{2}{*}{ Private } & Limited & $-21.143^{*}$ & 5.550 & 0.001 & -34.853 & -7.434 \\
\hline & & Public & 6.300 & 7.355 & 0.693 & -11.867 & 24.467 \\
\hline \multirow{6}{*}{$\begin{array}{l}\text { Company } \\
\text { size }\end{array}$} & \multirow[b]{2}{*}{$\begin{array}{l}\text { Less than } \\
\text { employees }\end{array}$} & 5-20 employees & $-21.427 *$ & 2.037 & 0.000 & -26.461 & -16.393 \\
\hline & & $\begin{array}{l}\text { More than } 20 \\
\text { employees }\end{array}$ & $-20.367 *$ & 3.416 & 0.000 & -28.805 & -11.928 \\
\hline & \multirow{2}{*}{ 5-20 employees } & $\begin{array}{l}\text { Less than } 5 \\
\text { employees }\end{array}$ & $21.427 *$ & 2.037 & 0.000 & 16.393 & 26.461 \\
\hline & & $\begin{array}{l}\text { More than } 20 \\
\text { employees }\end{array}$ & 1.060 & 2.980 & 0.939 & -6.302 & 8.423 \\
\hline & \multirow{2}{*}{$\begin{array}{l}\text { More than } 20 \\
\text { employees }\end{array}$} & $\begin{array}{l}\text { Less than } 5 \\
\text { employees }\end{array}$ & $20.367^{*}$ & 3.416 & 0.000 & 11.928 & 28.805 \\
\hline & & 5-20 employees & -1.060 & 2.980 & 0.939 & -8.423 & 6.302 \\
\hline \multirow{6}{*}{$\begin{array}{l}\text { Company } \\
\text { age }\end{array}$} & \multirow[b]{2}{*}{$\begin{array}{l}\text { Less } \\
\text { years }\end{array}$} & From 5-10 years & $-21.427 *$ & 2.037 & 0.000 & -26.461 & -16.393 \\
\hline & & $\begin{array}{l}\text { More than } 10 \\
\text { years }\end{array}$ & $-20.367^{*}$ & 3.416 & 0.000 & -28.805 & -11.928 \\
\hline & \multirow{2}{*}{ From 5-10 years } & $\begin{array}{l}\text { Less than } 5 \\
\text { years }\end{array}$ & $21.427^{*}$ & 2.037 & 0.000 & 16.393 & 26.461 \\
\hline & & $\begin{array}{l}\text { More than } 10 \\
\text { Years }\end{array}$ & 1.060 & 2.980 & 0.939 & -6.302 & 8.423 \\
\hline & \multirow{2}{*}{$\begin{array}{l}\text { More than } 10 \\
\text { years }\end{array}$} & $\begin{array}{l}\text { Less than } 5 \\
\text { years }\end{array}$ & $20.367 *$ & 3.416 & 0.000 & 11.928 & 28.805 \\
\hline & & From $5-10$ years & -1.060 & 2.980 & 0.939 & -8.423 & 6.302 \\
\hline
\end{tabular}

Dependent variable: Social media usage.

*The mean difference is significant at the 0.001 level.

The results show that there is a difference in social media usage between limited liability and public shareholding companies, were limited liability companies have the highest value for the use of social media. Furthermore, comes in second private shareholding companies as the mean difference between it and private shareholding companies is 21.143 and the lowest value is public shareholding companies in using social media were the mean difference between it and limited liability companies is 27.443 which indicated a significant difference compared to limited liability companies with private shareholding companies. In addition, medium companies (5-20 employees) have the highest value for the use of social media, then large companies (more than 20 employees) as the mean difference between it and small companies (less than 5 employees) is 20.367, and the lowest value is for small companies in using social media were mean difference between it and medium companies is 21.427. Also, relatively new companies (from 5 - 10 years old) have the highest value for the use of social media. Furthermore, comes in second old companies (more than 10 years old) the mean difference between it and new or young companies (less than 5 years old) is 20.367, and the lowest value is for new or young companies in using social media were mean the difference between it and relatively new companies is 21.427. The implication of these findings is discussed in the next section.

\section{Discussion}

The result of the study shows that there is a robust, direct and positive impact of social media usage on organizational performance in the Jordanian Dead Sea cosmetic sector. All independent variables have a high degree of integration for the social media for marketing, social media for customer relations and services, and social media for information accessibility variables (Parveen et al., 2016). The results indicate that there is a positive direct impact of social media usage for customer relations and information accessibility on rapid adaptation, this result is in harmony with previous research results (Dubois et al., 2004; Kimani, 2015; Parveen et al., 2016; Parveen et al., 2015) which indicated that social media usage adds much value to the organizations by allowing to directly connect with clients, particularly the ones in different geographic zones (Kimani, 2015), and by helping the organizations to effectively respond rapidly to changes in the internal or external work 
environment. Also, social media supports to retrieve additional information about the organization's competitors, their actions, their strategies, and their brand public views, which can help them improve their products and services (Stone et al., 2007). Therefore, using social media to provide rich information with better customer support as quickly as possible helps to increase the annual sales and financial gain, helps connect businesses to customers, build up relationships and cultivate those relationships (Coen, 2016; Kaplan and Haenlein, 2010).

Using social media to track the activities of competitors and analyzing the result to use in business helps to upgrade business followed by upgrading plans, such as offering discounts to attract more customers (Caruso, 2016). However, this study results also indicate that social media usage for marketing has a negative relationship with rapid adaptation, this may be because companies in this sector are not utilizing social media usage appropriately for marketing. For instance, Hajli (2014) noted to the fact that, in order for social media marketing to be successful and able to reach the target audience it has to be combined with trust and good content in order for it to be able to reach the customers regardless of their geographical existence or orientation. Accordingly, the influence of social media in reaching the target audience should be based on paying extra attention to the quality and content of the ads more than the quantity (Pradiptarini, 2011). The fact that social media is an open world for people of all ages makes it sensitive when it comes to advertising through those means. Therefore, organizations must take extra care of the content and the quality of the advertisements that are being published (Tatar and Eren-Erdoğmuş, 2016).

In the business sector, the internet is playing a big part in the facilitation and conducting the managerial work easier and cost effective. For instance, marketing and promotions are being done through social media based on its cheap cost and ability to reach different places at the same time regardless of the geographical place (Amedie, 2015). Accordingly, this study found that there is a positive direct impact of social media usage for marketing and information accessibility on cost reduction, these results are in harmony with the previous results (Apigian et al., 2005; Parveen et al., 2015; Shuai, and Wu, 2011; Stone et al., 2007), where social media usage can lower the cost of marketing (Parveen et al., 2016) by keeping updated and followed with trends and new social media sites to get a competitive advantage, also by systematically collecting customers feedback on social media sites and to search for competitors' information. Similarly, social media usage could be utilized in developing or commercializing a product or service (Afonso et al., 2008; Lam, 2016).

One of the essential uses of social media is that innovation can be encouraged by observing customer communications, feedback, and opinions (Matuszak, 2007; Tapscott and Williams, 2006). Accordingly, the results indicate that there is a positive direct impact of social media usage for customer relations information accessibility on innovation, this is in line with previous results that show a definite movement happening to power social media to facilitate drive higher levels of product innovation and profitability (Kenly and Poston, 2011; Wright et al., 2001). Accordingly, social networking leads to improved levels of employee productivity with the advantage of escalating cooperation that will encourage knowledge sharing among individuals, with the potential of improved productivity and innovation (Jagero, 2014). Also, social media usage can help organizations to be more innovative, proactive, and risk-taking (Parveen et al., 2016), also in digital advertising and promotion, handling customer service issues, mining innovative ideas and building customer relations (Solis, 2010). Organizations using social media are eager to take risks and invest in new products and services to satisfy customers, to get improved feedback, and develop the brand image. In addition, social media provide the source and distribution platforms that contribute to information transfer for constant knowledge by enabling more participatory and interactive learning experience (Salem et al., 2017). Therefore, entrepreneurs in the small industries need to understand the techniques to influence their brands and services through electronic word of mouth communication process in social media, and features like participation, social connection, innovativeness and experiences are the key factors contributing to spread electronic word of mouth in social networks (Leung and Baloglu, 2015), which can help the organization in competitive business environment (Kucukemiroglu and Kara, 2015).

It is clear that most companies in the Dead Sea cosmetic sector in Jordan are limited liability companies $(60 \%)$, while the least is public shareholding (17\%), and most of them considered as medium-size companies $(52 \%)$, this indicates that this industry is still small with the ability to be developed more alongside with the support from the Jordanian government. Also, there is a high social media usage among limited liability companies unusually medium and relatively new companies which could be owing to hiring young and new graduate employees "millennials" who are social media enthusiasts and concerned of implementing there social media expert on their work and reflecting the new university education which includes a lot of educational materials regarding E-business, E-marketing, E-commerce (Cho et al., 2013). Also, it could be for the focusing of these companies on training their employees on using and implement social media usage within their required tasks. However, there is a lack of social media usage in public shareholding companies unusually large and old companies usually, because there are no young and new graduate employees "millennials" within the company. Also, old companies usually focus on their marketing strategies on only distribution contracts with other agencies for them to market their products with no or small marketing support, this draws attention to these 
specific companies to hire more employees who have E-Marketing experience within their marketing department.

\subsection{Practical Implications}

This study reports the various purposes for which the social media can be used successfully. Accordingly, organizations in the Jordanian Dead Sea sector can understand the various usages of social media that can improve performance and choose those that are suitable for their business (Parveen et al., 2016). Therefore, it is recommended to further engage customers through social media platforms in designing the company's products which will positively affect the integration with customers. In addition, companies must focus on enhancing the flexibility of its marketing strategies through the openness in social media platforms to new ideas and thoughts. Accordingly, Dead Sea cosmetic industry must empower social media usage especially for public shareholding companies, since it is important to increase organizational performance, by creating new ways of innovation in products, rapid adaptation to the market needs, and the reduction of marketing costs, this could be through hiring more employees who have E-Marketing experience within their marketing department, and recruiting higher education employees to enrich the company with various talents and knowledge in different fields and areas, which will lead to more effectiveness and efficiency within the company. Also, companies should be paying extra attention to the quality and content of the ads more than the quantity. Therefore, organizations must take extra care of the content and the quality of the advertisements that are being published.

\subsection{Limitations and Future Research}

In this study, in order to investigate social media usage and its impact, only certain factors were included. In a broader context, there may be other antecedents and impact factors. Therefore, the investigation of only certain factors in the study may be considered a limitation. Other antecedents and drivers as a result of social media usages such as organizational learning (Senge et al., 1999) and absorptive capacity (Jiménez-Barrionuevo et al., 2011) could be analyzed. In addition, generalizing the research results is limited to the research sample, and the results must be taken with concern, as this study only investigated social media use within Jordanian companies in Dead Sea sector. Therefore, future research is needed in other sectors and industries in Jordan. In order to generalize the research results, future research can apply the same model but to wider number of organizations. In addition, it would be interested to replicate the study in the same context of Dead Sea cosmetic sector in Israel and compare the results. It is also advised to perform similar studies from the customer's viewpoint. Also, this study depended primarily on questionnaire to gather related data, which is not free of bias. Therefore, future research is suggested by using other approaches like interviews or focus group for a better understanding of the study phenomenon. Furthermore, this study investigated the usage of social media considering social media tools in general. Since each social media tool and site has unique features and offers various benefits, future studies could focus on studying one social media site in particular such as Facebook and investigate it in detail, which might offer more in-depth understanding on social media and its impact on organizations. Also, future studies should be conducted to compare the results between different countries and cultures for validation purposes. Finally, this study used a cross-sectional sample to collect data. Therefore, future researchers can conduct a longitudinal study to investigate the relationship between social media usage and organizational performance.

\section{Conclusion}

The purpose of this study was to investigate whether different types of social media usage would either increase or decrease organizational performance in Dead Sea industry in Jordan, to gain a richer picture of the positive effects social media usage may yield. The findings suggested that there is a positive relationship between social media for marketing, for customer relations and services, and for information accessibility and organizational performance in terms of rapid adaptation, cost reduction, and innovation. Also, the results suggested that social media usage is related to the company's characteristics such as type, age, and type. Accordingly, the usage of social media can grant the company a competitive advantage edge upon competitors throughout rapidly adapt to internal and external changes in the environment, and achieve the changing requirements of consumers in a short period. This study has contributed to social media research by providing a clearer idea of the real importance of social media usage and its benefits in various areas of organizational performance that can be improved through social media usage. Furthermore, this study helps managers and decision makers especially in the Jordanian Dead Sea industry to understand the real importance of social media usage which will improve the performance of the organization in various areas.

\section{Acknowledgements}

This research did not receive any specific grant from funding agencies in the public, commercial, or not-forprofit sectors. 


\section{References}

Afonso, P., Nunes, M., Paisana, A., and Braga, A. (2008). The influence of time-to-market and target costing in the new product development success. International Journal of Production Economics, Vol. 115 No. 2, pp.559 -568.

Ainin, S., Parveen, F., Moghavvemi, S., Jaafar, N. I., and Mohd Shuib, N. L. (2015). Factors influencing the use of social media by SMEs and its performance outcomes. Industrial Management \& Data Systems, Vol. 115 No. 3, pp.570-588.

Akar, E and Topçu, B. (2011). An examination of the factors influencing consumers' attitudes toward social media marketing, Journal of Internet Commerce, Vol. 10 No. 1, pp.35-67.

Al Tawara, A., and Gide, E. (2017). A comprehensive literature review on the adoption of social media marketing in some retailers in Jordan. International Journal of Business and Management Studies, Vol. 6 No. 1, pp.221-256.

Alkhoms, A., and Alnsour, M. S. (2013). Social media marketing and relationship quality: Zain Jordan customers' perspective. European Journal of Business and Management, Vol. 5 No. 25, pp.2222-2839.

Al-Weshah, G., Al-Hyari, K., Abu-Elsamen, A., and Al-Nsour, M. (2011). Electronic Networks and Gaining Market Share: Opportunities and Challenges. International Journal of Information Communication Technologies and Human Development, Vol. 3 No. 3, pp.1-15.

Amedie, J., (2015). The impact of social media on society. Advanced Writing: Pop Culture Intersections, 2. http://scholarcommons.scu.edu/engl_176/2 (Accessed 10 July 2018).

Ashton, W. B., and Klavans, R. A. (1997). An introduction to technical intelligence in business. Keeping abreast of science and technology: technical intelligence for business.

Barker, M., Barker, D. I., Bormann, N., and Neher, K. (2012). Social media marketing: A strategic approach. Nelson Education.

Bassellier, G., and Benbasat, I. (2004). Business competence of information technology professionals: Conceptual development and influence on IT-business partnerships. MIS Quarterly, Vol. 28 No. 4, pp.67 694.

Berthon, P. R., Pitt, L. F., Plangger, K., and Shapiro, D. (2012). Marketing meets Web 2.0, social media, and creative consumers: Implications for international marketing strategy. Business Horizons, Vol. 55 No. 3 , pp.261-271.

Boshoff, C., and Elliot, R. (2005). The influence of organisational factors in small tourism businesses on the success of Internet marketing. Management Dynamics: Journal of the Southern African Institute for Management Scientists, Vol. 14 No. 3, pp.44-58.

Boxall, P. (2003). HR strategy and competitive advantage in the service sector. Human Resource Management Journal, Vol. 13 No. 3, pp.5-20.

Bryman, A., and Cramer, D. (2012). Quantitative data analysis with IBM SPSS 17, 18 \& 19: A guide for social scientists. Routledge.

Bughin, J. (2015). Getting a sharper picture of social media's influence. McKinsey Quarterly, July, 8.

Caruso, C. (2016). Can a Social-Media Algorithm Predict a Terror Attack?. MIT Technology Review. https://www.technologyreview.com/s/601700/can-a-social-media-algorithm-predict-a-terror-attack/ (Accessed 20 July 2018).

Chaffey, D. (2016). Global social media research summary 2018. Smart Insights: Social Media Marketing.

Chang, S.E., Shen, W.C., and Liu, A.Y. (2016). Why mobile users trust smartphone social networking services? A PLS-SEM approach, Journal of Business Research, Vol. 69 No. 11, pp.4890-4895.

Chin, W. W. (1998). The partial least squares approach to structural equation modeling. Modern Methods for Business Research, Vol. 295 No. 2, pp.295-336.

Cho, J., Park, D. J., and Ordonez, Z. (2013). Communication-oriented person-organization fit as a key factor of job-seeking behaviors: Millennials' social media use and attitudes toward organizational social media policies. Cyberpsychology, Behavior, and Social Networking, Vol. 16 No. 11, pp.794-799.

Coen, B. (2016). Using social media for customer relationship management. Social Media Today. https://www.socialmediatoday.com/social-business/using-social-media-customer-relationship-management (Accessed 8 June 2018).

Dane, M. (2016). 8 ways to get more website traffic via social media. Maximize Social Business. https://maximizesocialbusiness.com/how-to-drive-website-traffic-with-instagram-22950/ (Accessed 8 June 2018).

Davis Mersey, R., Malthouse, E. C., and Calder, B. J. (2010). Engagement with online media. Journal of Media Business Studies, Vol. 7 No. 2, pp39-56.

DeLone, W. H., and McLean, E. R. (1992). Information systems success: The quest for the dependent variable. Information Systems Research, Vol. 3 No. 1, pp.60-95.

Derham, R., Cragg, P., and Morrish, S. (2011). Creating value: An SME and Social Media. Paper Presented at 
the Pacific Asia Conference on Information Systems. 1-9 July 2011.

Dubois, D. D., Rothwell, W. J., Stern, D. J., and Kemp, L. K. (2004). Competency-based Human Resource Management. Palo Alto, CA: Davies-Black Publishing.

Efron, B. (1979). Computers and the theory of statistics: thinking the unthinkable. SIAM Review, Vol. 21 No. 4 , pp.460-480.

Eisenfeld, B., and Fluss, D. (2009). Contact centers in the web 2.0 world. CRM Magazine, Vol. 13 No. 2, pp.4849.

Evans, C., and Erkan, I. (2014). The impacts of electronic word of mouth in social media on consumers purchase intentions. Unpublished $\mathrm{PhD}$ thesis, Brunel University, London, UK.

Feher, A., and Towell, E. (1997). Business use of the Internet. Internet Research, Vol. 7 No. 3, pp.195-200.

Ferrer, E., Bousoño, C., Jorge, J., Lora, L., Miranda, E., and Natalizio, N. (2013). Enriching social capital and improving organizational performance in the age of social networking. Business and Management, Vol. 5 No. 2, pp. 94-281.

Gironda, J. T., and Korgaonkar, P. K. (2014). Understanding consumers' social networking site usage. Journal of Marketing Management, Vol. 30 No. 5-6, pp.571-605.

Gonzalez, R., Llopis, J., and Gasco, J. (2015). Social networks in cultural industries. Journal of Business Research, Vol. 68 No. 4, pp.823 - 828.

Gordhamer, S. (2009). Four ways social media is challenging business. http://Mashable.com/2009/09/22/spcialMedia-Business/ (Accessed 1 May 2018).

Graef, J. L. (1997). Using the Internet for competitive intelligence: a survey report. Competitive Intelligence Review, Vol. 8 No. 4, pp.41-47.

Gruen, T. W., Osmonbekov, T., and Czaplewski, A. J. (2006). eWOM: The impact of customer-to-customer online know-how exchange on customer value and loyalty. Journal of Business Research, Vol. 59 No. 4, pp.449-456.

Hair, J., Hollingsworth, C. L., Randolph, A. B., and Chong, A. Y. L. (2017). An updated and expanded assessment of PLS-SEM in information systems research. Industrial Management \& Data Systems, Vol. 117 No. 3, pp.442-458.

Hajli, M. N. (2014). A study of the impact of social media on consumers. International Journal of Market Research, Vol. 56 No. 3, pp.387-404.

Harris, A. L., and Rea, A. (2009). Web 2.0 and virtual world technologies: A growing impact on IS education. Journal of Information Systems Education, Vol. 20 No. 2, pp.137.

Hassan, S., Nadzim, S. Z. A., and Shiratuddin, N. (2015). Strategic use of social media for small business based on the AIDA model. Procedia-Social and Behavioral Sciences, Vol. 172, pp.262-269.

Hoyer, W. D., MacInnis, D. J., and Pieters, R. (2010). Comportamiento del consumidor. México: Cengage Learning.

Huang, K. F. (2011). Technology competencies in competitive environment. Journal of Business Research, Vol. 62 No. 2 , pp.172-179.

Jackson, C. (2011). Your students love social media... and so can you. Teaching Tolerance, Vol. 39, pp.38-41.

Jagero, N. (2014) Impact of access to social media on employee productivity and organisational performance at Econet Wireless Zimbabwe. International Journal of Knowledge and Research in Management \& ECommerce. Vol. 4 No. 1, pp.20-31.

Jarad, G. A. (2014). Marketing over social media networks'. Marketing, Vol. 6 No. 13.

Jiménez-Barrionuevo, M.M., García-Morales, V.J. and Molina, L.M. (2011). Validation of an instrument to measure absorptive capacity, Technovation, Vol. 31 No. 5-6, pp.190-202.

Kaplan, A. M., and Haenlein, M. (2010). Users of the world, unite! The challenges and opportunities of Social Media. Business Horizons, Vol. 53 No. 1, pp.59-68.

Kassler, H. S. (1997). Mining the Internet for competitive intelligence. Online, 21(5), 34-45.

Keegan, B. J., and Rowley, J. (2017). Evaluation and decision making in social media marketing. Management Decision, Vol. 55 No. 1, pp.15-31.

Kenly, A., and Poston, B. (2011). Social media and product innovation: early adopters reaping benefits amidst challenge and uncertainty. Kalypso White Paper. S, pp.1-8.

Kim, A. J., and Ko, E. (2012). Do social media marketing activities enhance customer equity? An empirical study of luxury fashion brand. Journal of Business Research, Vol. 65 No. 10, pp.1480-1486.

Kim, E., Sung, Y., and Kang, H. (2014). Brand followers' retweeting behavior on Twitter: How brand relationships influence brand electronic word-of-mouth. Computers in Human Behavior, Vol. 37, pp.18-25.

Kimani, E. (2015). Role of social media marketing on organisational performance in Kenya. Journal of Business and Management, Vol. 17 No. 1, pp.101-105.

Kucukemiroglu, S., and Kara, A. (2015). Online word-of-mouth communication on social networking sites: An empirical study of Facebook users. International Journal of Commerce and Management, Vol. 25 No. 1, 
pp.2-20.

Kumar, N., Stern, L. W., and Anderson, J. C. (1993). Conducting interorganizational research using key informants. Academy of Management Journal, Vol. 36 No. 6, pp.1633-1651.

Kwok, L., and Yu, B. (2013). Spreading social media messages on Facebook: An analysis of restaurant businessto-consumer communications. Cornell Hospitality Quarterly, Vol. 54 No. 1, pp.84-94.

Lam, (2016). Using social media to develop and commercialise new ICT products. Unpublished Master Thesis, Aalto University, Helsinki, Finland.

LaRose, R., and Hoag, A. (1996). Organizational adoptions of the Internet and the clustering of innovations. Telematics and Informatics, Vol. 13 No. 1, pp.49-61.

Leeflang, P. S., Verhoef, P. C., Dahlström, P., and Freundt, T. (2014). Challenges and solutions for marketing in a digital era. European Management Journal, Vol. 32 No. 1, pp.1-12.

Leung, X. Y., and Baloglu, S. (2015). Hotel Facebook marketing: an integrated model. Worldwide Hospitality and Tourism Themes, Vol. 7 No. 3, pp.266-282.

Loten, A., Janofsky, A., and Albergotti, R. (2014). New Facebook rules will sting entrepreneurs. The Wall Street Journal. http://www.oxfordrmg.com/wp-content/uploads/2014/12/New-Facebook-Rules-Will-Sting-SmallBusinesses.pdf

Mangold, W. G., and Faulds, D. J. (2009). Social media: The new hybrid element of the promotion mix. Business Horizons, 52(4), 357-365.

Matuszak, G. (2007), Enterprise 2.0: fad or future? The business role for social software platforms: KPMG. www.kpmg.ca/en/industries/ice/documents/thebusinessroleforsocialsoftwareplatforms (Accessed 3 March 2018).

Min, H., and Galle, W. P. (2003). E-purchasing: profiles of adopters and nonadopters. Industrial Marketing Management, Vol. 32 No. 3, pp.227-233.

Moen, Ø., Koed Madsen, T., and Aspelund, A. (2008). The importance of the internet in international businessto-business markets. International Marketing Review, Vol. 25 No. 5, pp.487-503.

Mourtada, R. and Alkhatib, F. (2014). 2014 UAE Social Media Outlook: Increasing Connectivity Between Government and Citizen, Dubai Press Club, Dubai.

Muk, A., and Chung, C. (2014). Driving consumers to become fans of brand pages: A theoretical framework. Journal of Interactive Advertising, Vol. 14 No. 1, pp.1-10.

Nunnally, J. C., and Bernstein, I. H. (1994). Psychometric Theory (McGraw-Hill Series in Psychology), New York: McGraw-Hill.

Okazaki, S., and Taylor, C. R. (2013). Social media and international advertising: theoretical challenges and future directions. International Marketing Review, Vol. 30 No. 1, pp.56-71.

Olof Lagrosen, S., and Grundén, K. (2014). Social media marketing in the wellness industry. The TQM Journal, Vol. 26 No. 3, pp.253-260.

Özer, Ö., and Uncu, O. (2015). Integrating dynamic time-to-market, pricing, production and sales channel decisions. European Journal of Operational Research, Vol. 242 No. 2, pp.487-500.

Paniagua, J., and Sapena, J. (2014). Business performance and social media: Love or hate?. Business Horizons, 57(6), 719-728.

Papastathopoulou, P., and Avlonitis, G. J. (2009). Classifying enterprises on the basis of WWW use: A behavioral approach. Internet Research, Vol. 19 No. 3, pp.332-347.

Paridon, T. J., and Carraher, S. M. (2009). Entrepreneurial marketing: Customer shopping value and patronage behavior. Journal of Applied Management and Entrepreneurship, Vol. 14 No. 2, pp.3.

Parveen, F., Jaafar, N. I., and Ainin, S. (2013). Social media usage among businesses: a website content analysis. Asian Journal of Information Technology, Vol. 12 No. 10, pp.342-348.

Parveen, F., Jaafar, N. I., and Ainin, S. (2015). Social media usage and organizational performance: Reflections of Malaysian social media managers. Telematics and Informatics, Vol. 32 No. 1, pp.67-78.

Parveen, F., Jaafar, N. I., and Ainin, S. (2016). Social media's impact on organizational performance and entrepreneurial orientation in organizations. Management Decision, Vol. 54 No. 9, pp.2208-2234.

Patino, A., Pitta, D.A., and Quinones, R. (2012). Social media's emerging importance in market research. Journal of Consumer Marketing, 29(3), 233-237.

Podsakoff, P. M., MacKenzie, S. B., Lee, J. Y., and Podsakoff, N. P. (2003). Common method biases in behavioral research: A critical review of the literature and recommended remedies. Journal of Applied Psychology, Vol. 88 No. 5, pp.879.

Pradiptarini, C. (2011). Social media marketing: Measuring its effectiveness and identifying the target market. UW-L Journal of Undergraduate Research, Vol. XIV, pp.1-12.

Rodriguez, M., Peterson, R. M., and Ajjan, H. (2015). CRM/social media technology: impact on customer orientation process and organizational sales performance. Presented in Ideas in Marketing: Finding the New and Polishing the Old, pp.636-638. Springer, Cham. 
Rogers, E. M., and Murcott, S. (1995). Attributes of innovations and their rate of adoption. Diffusion of Innovations, pp.204-251.

Salem, J., Borgmann, H., MacNeily, A., Boehm, D., Schmid, M., Groeben, C., Baunacke, M., and Huber, J. (2017). New media for educating urology residents: an interview study in Canada and Germany, Journal of Surgical Education, Vol. 74 No. 3, pp.495-502.

Saunders, M., Lewis, P. and Thornhill, A. (2016). Research methods for business students. Harlow: Pearson Education Limited.

Schultz, R. J., Schwepker Jr, C. H., and Good, D. J. (2012). Social media usage: an investigation of B2B salespeople. American Journal of Business, Vol. 27 No. 2, pp.174-194.

Schulz, D.E., and Peltier, J. (2013). Social media's slippery slope: Challenges, opportunities and future research directions. Journal of Research in Interactive Marketing, Vol. 7 No. 2, pp.86-99.

Scott, D. M. (2009). World wide rave: Creating triggers that get millions of people to spread your ideas and share your stories. Hoboken, NJ: John Wiley \& Sons. Doi:10.1002/9781118258286

Scupola, A., and Nicolajsen, H. W. (2013). Using social media for service innovations: challenges and pitfalls. International Journal of E-Business Research, Vol. 9 No. 3, pp.27-37.

Senge, P., Kleiner, A., Roberts, C., Roth, G., and Ross, R. (1999). The dance of change: the challenges of sustaining the learning organization, Doubleday, New York, NY.

Shuai, J. J., and Wu, W. W. (2011). Evaluating the influence of E-marketing on hotel performance by DEA and grey entropy. Expert Systems with Applications, Vol. 38 No. 7, pp.8763-8769.

Smith, A. N., Fischer, E., and Yongjian, C. (2012). How does brand-related user-generated content differ across YouTube, Facebook, and Twitter?. Journal of Interactive Marketing, Vol. 26 No. 2, pp.102-113.

Soh, C., Yong Mah, Q., Jek Gan, F., Chew, D., and Reid, E. (1997). The use of the Internet for business: the experience of early adopters in Singapore. Internet Research, Vol. 7 No. 3, pp.217-228.

Solis, B. (2010). Engage: The complete guide for brands and businesses to build, cultivate, and measure success in the new web. John Wiley \& Sons.

Stelzner, M. (2016). Social media industry report. How marketers are using social media to grow their businesses. Luettavissa. https://www. socialmediaexaminer.com/wpcontent/uploads/2016/05/SocialMediaMarketingIndustryReport2016.pdf (Accessed 15 March 2018).

Stone, R. W., Good, D. J., and Baker-Eveleth, L. (2007). The impact of information technology on individual and firm marketing performance. Behaviour \& Information Technology, Vol. 26 No. 6, pp.465-482.

Tamimi, T., F., H. (2012). The impact of innovation in the marketing mix elements of Jordan Dead Sea products on enhancing its competitiveness position in the international markets: A field study on a sample manufacturers and exporters of Dead Sea Products in Jordan. Unpublished Master Thesis, Open Arab Academy, Amman, Jordan.

Tamimi, T.F.H. (2017). Key factors influencing international marketing strategies of Dead Sea products sector in Jordan. Unpublished PhD Thesis, Al-Madinah International University, Kuala Lumpur, Malaysia.

Tapscott, D. and Williams, A.D. (2006). Wikinomics: How mass collaboration changes everything, Portfolio, New York, NY.

Tatar, Ş. B., and Eren-Erdoğmuş, İ. (2016). The effect of social media marketing on brand trust and brand loyalty for hotels. Information Technology \& Tourism, Vol. 16 No. 3, pp.249-263.

Telecommunications Regulatory Commission, (2017). Business https://jordan.gov.jo/wps/portal/Home/OpenDataMain/OpenDataUser/\#/viewDataSet/170 (Accessed 12 March 2018).

Teo, T. S., and Choo, W. Y. (2001). Assessing the impact of using the Internet for competitive intelligence. Information \& Management, Vol. 39 No. 1, pp.67-83.

Thackeray, R., Neiger, B. L., Hanson, C. L., and McKenzie, J. F. (2008). Enhancing promotional strategies within social marketing programs: use of Web 2.0 social media. Health Promotion Practice, Vol. 9 No. 4 , pp.338-343.

Thong, J. Y. (2001). Resource constraints and information systems implementation in Singaporean small businesses. Omega, Vol. 29 No. 2, pp.143-156.

Thornton, B., and Gupta, S. (2004). Comparative validation of a partial (versus full) randomized response technique: attempting to control for social desirability response bias to sensitive questions. Individual Differences Research, 2(3).

Tikkanen, H., Hietanen, J., Henttonen, T., and Rokka, J. (2009). Exploring virtual worlds: success factors in virtual world marketing. Management Decision, Vol. 47 No. 8, pp.1357-1381.

Trainor, K.J., Andzulis, J., Rapp, A., and Agnihotri, R. (2014). Social media technology usage and customer relationship performance: a capabilities-based examination of social CRM, Journal of Business Research, Vol. 67 No. 6, pp.1201-1208. 
Tsitsi Chikandiwa, S., Contogiannis, E., and Jembere, E. (2013). The adoption of social media marketing in South African banks. European Business Review, Vol. 25 No. 4, pp.365-381.

Velázquez, B. M., Blasco, M. F., and Gil Saura, I. (2015). ICT adoption in hotels and electronic word-of-mouth. Academia Revista Latinoamericana de Administración, Vol. 28 No. 2, pp.227-250.

Weinberg, T. (2009). The new community rules: Marketing on the social web. O'Reilly Media, Inc.

Wright, P. M., Dunford, B. B., and Snell, S. A., (2001). Human resources and the resource-based view of the firm. Journal of Management, Vol. 5 No. 2, pp.701-721.

Yaseen, H, Dingley, K, and Adams, C. (2016). Capturing the growth of e-commerce in Jordan using a novel research approach. International Journal of Management and Commerce Innovations, Vol. 3 No. 2 , pp.811-827.

Zarella, D. (2010). The Social Media Marketing Book, Sebastopol, CA: O’Reily Media.

Zyl, S., V., A. (2009). The impact of Social Networking 2.0 on organisations. The Electronic Library, Vol. 27 No. 6, pp.906-918.

\section{Appendix A. Measures and Sources}

Social Media for Marketing

1. The company uses social media to advertise their products.

2. The company is seeking through the means of social media to promote its brand.

3. The company operates through the means of social media in the evaluation of its performance marketing by getting feedback from (Likes, shares and follow-up of Instagram, Facebook, and Twitter).

4. The company uses different languages in marketing through social media.

5. The company kept pace with trends and new social media sites to get a competitive advantage.

Social Media for Customer's Relations and Services

1. The company systematically collected customer feedback on social media sites.

2. The company develops its relationship with customers through constant communication with them through the means of social media.

3. The company operates through the means of social media in doing customer service activities.

4. The company improved the quality of their products through the study of customer feedback through social media.

5. The company is seeking to reach out to new customers through social media.

Social Media for Information Accessibility

1. The company operates through the means of social media in the search for general information about the target market.

2. The company uses social media to search for competitors' information.

3. The company provides through the means of social media full information about the cost and the expected date of delivery.

4. The company uses social media to provide full details of their products.

5. The company is working to create and update a database to its customers through the means of social media.

Source: (Graef, 1997; Kassler, 1997; Moen et al., 2008, Teo and Choo, 2001).

Rapid Adaptation

1. The company possesses the ability to respond rapidly to changes in the work environment (internal or external variables).

2. The company chooses suppliers are characterized by flexibility in responding to requests by the company when needed.

3. The company has expertise and capabilities in R\&D department able to keep pace with the rapid changes in the work environment.

4. The company urgently needed changes in the conduct by the agent in the product characteristics.

5. The company has the ability to develop existing products within a short period of time (less than six months).

Time to Market

1. The company continues to invest in advanced technology to improve their products and services.

2. The company relies on feedback from customers to help determine the most appropriate time to launch new products on the market.

3. The company works to enter into new markets and regions to help spread globally.

4. The company used a variety of marketing techniques to help increase the awareness and knowledge of customers for new products on the market.

Cost Reduction

1. Using social media reduce the cost of communication with customers. 
2. Using social media reduce the cost of advertising and promotion.

3. Using social media reduce the cost of customer service and support.

Innovation

1. The company characterized by innovation in production methods.

2. The company applied new innovative methods in advertising their products and services.

3. The company is always looking for new innovative ways to deliver their products ways.

4. The company decided to change the properties of the shape of the product and its quality on the basis of a new innovative idea.

5. The company encourages new innovative ideas.

Source: (Ashton and Klavans, 1997; Boxal, 2003; DeLone and McLean, 1992; Feher and Towell, 1997; Soh et al., 1997; Teo and Choo, 2001). 